\title{
IQs and etiologies: The two-group approach to mental retardation
}

\author{
CHARLES C. CLELAND, JAN CASE, and GUY J. MANASTER \\ University of Texas, Austin, Texas 78712
}

\begin{abstract}
A review of the mental retardation literature failed to reveal any empirical studies supporting the assumption that "the retardate having an extremely low I.Q. (below 40) is almost invariably of the physiologically defective type ... (while familial retardates . . . are almost invariably mildly retarded)" (Zigler, 1967, p. 1). Thus, the two-group approach to mental retardation, despite its research and clinical implications, rests on assumption. We report herein on 20,218 institutionalized retardates on whom both IQ and etiologies were available. For institutionalized retardates, the criterion of "invariability" was not met. Since our sample was small relative to the total estimated retarded population, the two-group theory still retains research and practical merit, and suggestions for increasing its heuristic value are provided.
\end{abstract}

Zigler's $(1967,1969)$ two-group approach to mental retardation has rested on an assumption, thought to be fact and accepted throughout this century (Heber, 1961; Sarason, 1949): "The retardate having an extremely low I.Q. (below 40) is almost invariably of the physiologically defective type. Familial retardates, on the other hand, are almost invariably mildly retarded" (Zigler, 1967, p. 1).

The influence of this assumption is so great it underlies much research and many clinical decisions. One would expect that a "fact" of this magnitude would be heavily documented. However, no large studies exist to support this notion, which appears to have its origin in Penrose's (Note 1) study of 1,280 British retardates, many of whom by current classification would not be retarded. The purpose of this study was to investigate the relationship between IQ and etiology and to ascertain the validity of the above assumption.

A number of conceptual and definitional issues had to be dealt with prior to the study. In essence, 96\%-97\% of mentally retarded persons are not in institutions (Robinson \& Robinson, 1965), and half or more of those institutionalized have no specific etiological assignment (Hutt \& Gibby, 1976). Of the total retarded population, $70 \%-80 \%$ are "cultural-familial" (Cleland, 1978), or the current equivalent, "psychosocial deprivation." Yet, the only adult retardates on whom substantial and accurate intellectual and etiological data exist are in institutions (Gladwin, 1959). We realize that the population sampled might not generalize to the total population of retardates, but the only feasible place to study IQs and etiologies is in institutions. Guidelines for describing diagnostic categories periodically change, but

The authors thank Edward Zigler, Sterling Professor of Psychology, Yale University, for his valuable suggestions. Thanks are also due the superintendents and staff of the participating institutions. those diagnosed as organic are unlikely to change; those for whom a social, cultural, or familial deprivation relationship can be shown also should not change, although the label has, whereas the "unknown" category will change as measurement improvements and causal factors are found. To this date, the gross categories organic, cultural-familial (or psychosocial deprivation), and unknown are most readily understood and will be used herein.

\section{METHOD}

Thirty-three $(20 \%)$ of the 166 state-supported facilities listed in the 1968 Directory of Residential Facilities (American Association on Mental Deficiency, 1968) were mailed request letters seeking the IQ and etiology of every resident on their rosters as of December 1976. Returns were received from 26 institutions, and 18 returns were detailed enough to allow unambiguous analyses. The final sample included $11 \%$ of the institutions listed in the 1968 Directory, and the 18 institutions whose data were employed are geographically representative. Thus, with a total $\mathrm{N}$ of 20,218 , our sample is both larger and more current than that of Penrose (Note 1) and should reflect the diagnostic advances ensuing over nearly 40 years.

\section{RESULTS}

Most difficult to deal with was the great difference in etiological assignments between institutions. For example, no familials were diagnosed at three institutions. At one, no familials were rated profound and $6 \%$ were rated severe, whereas $48 \%$ of the profounds were diagnosed unknown and $29 \%$ were diagnosed "other" (e.g., environmental deprivation or psychotic). At another, $59 \%$ of familials were rated profound or severe, and $31 \%$ of the profounds and $32 \%$ of the severe were diagnosed unknown. A third contrasting institution showed $50 \%$ of their familials were profound and $31 \%$ severe; yet, of the profounds at this institution, only $6 \%$ were diagnosed unknown and $7 \%$ of the severe were so diagnosed. 
Table 1

Mental Level by Diagnosis

\begin{tabular}{|c|c|c|c|c|c|c|c|c|c|c|c|}
\hline \multirow[b]{4}{*}{$\begin{array}{c}\text { Mental } \\
\text { Level }\end{array}$} & \multicolumn{11}{|c|}{ Diagnosis } \\
\hline & \multicolumn{3}{|c|}{ Organic } & \multicolumn{3}{|c|}{ Familial } & \multicolumn{3}{|c|}{ Unknown } & \multicolumn{2}{|c|}{ Total } \\
\hline & \multirow[b]{2}{*}{$\mathrm{N}$} & \multicolumn{2}{|c|}{ Percent of } & \multirow[b]{2}{*}{$\mathbf{N}$} & \multicolumn{2}{|c|}{ Percent of } & \multirow[b]{2}{*}{$\mathrm{N}$} & \multicolumn{2}{|c|}{ Percent of } & \multirow[b]{2}{*}{$\mathbf{N}$} & \multirow{2}{*}{$\begin{array}{c}\text { Percent } \\
\text { Mental } \\
\text { Level } \dagger\end{array}$} \\
\hline & & $\begin{array}{c}\text { Mental } \\
\text { Level }\end{array}$ & $\begin{array}{l}\text { Diag- } \\
\text { nosis }\end{array}$ & & $\begin{array}{c}\text { Mental } \\
\text { Level }\end{array}$ & $\begin{array}{l}\text { Diag- } \\
\text { nosis }\end{array}$ & & $\begin{array}{c}\text { Mental } \\
\text { Level }\end{array}$ & $\begin{array}{l}\text { Diag- } \\
\text { nosis }\end{array}$ & & \\
\hline $\begin{array}{l}\text { Profound } \\
\text { Severe } \\
\text { Moderate } \\
\text { Mild } \\
\text { Total* }\end{array}$ & $\begin{array}{r}8,084 \\
3,594 \\
1,801 \\
833 \\
14,312\end{array}$ & $\begin{array}{l}75.64 \\
68.54 \\
61.89 \\
60.49\end{array}$ & $\begin{array}{r}56.48 \\
25.11 \\
12.59 \\
5.82 \\
70.79\end{array}$ & $\begin{array}{r}333 \\
323 \\
271 \\
145 \\
1,072\end{array}$ & $\begin{array}{r}3.12 \\
6.16 \\
9.31 \\
10.53\end{array}$ & $\begin{array}{r}31.06 \\
30.13 \\
25.28 \\
13.53 \\
5.30\end{array}$ & $\begin{array}{r}2,271 \\
1,326 \\
838 \\
399 \\
4,834\end{array}$ & $\begin{array}{l}21.24 \\
25.29 \\
28.79 \\
28.94\end{array}$ & $\begin{array}{r}47.00 \\
27.42 \\
17.33 \\
8.25 \\
23.91\end{array}$ & $\begin{array}{r}10,688 \\
5,243 \\
2,910 \\
1,377 \\
20,218\end{array}$ & $\begin{array}{r}52.86 \\
25.93 \\
14.39 \\
6.81\end{array}$ \\
\hline
\end{tabular}

Note-2.53\% of the sample was diagnosed in other categories (e.g., environmental deprivation, psychotic, etc.), ranging from 1.65\% of the profounds to $5.06 \%$ of the moderates. These subjects were not included in these analyses, reducing the sample size from 20,743 to 20,218. *Percent diagnosis of total. TPercent mental level of total.

To speak of retardates in institutions, then, it is necessary to refer to composite or summed data across institutions. Such data may not exactly reflect the situation in any given institution, but they can address institutionalized retardates. The total sample, with diagnosis by mental level, is presented in Table 1, which shows the percentages of familials, organics, and unknowns for each mental level and the percentage of each diagnosis according to mental level. Table 1 illustrates the overwhelming majority of organics at all mental levels and also shows that the majority of all diagnostic groups-organics (82\%), unknowns (74\%), and familials (61\%)-are at the profound and severe levels.

\section{DISCUSSION}

Zigler (1967) said, "The retardate having an extremely low I.Q. (below 40) is almost invariably of the physiologically defective type. Familial retardates, on the other hand, are almost invariably mildly retarded, usually with I.Q.'s above 50 " (p. 292).

The data presented indicate otherwise, at least for institutionalized retardates. The difficulty with replying to Zigler's (1967) statement lies in the contrast between the two sentences above. His two sentences imply the following two sets of sentences: (1) "The retardate having an extremely low I.Q. (below 40) is almost invariably of the physiologically defective type." And thus, the retaidate having a moderate or mild level IQ (above 40) is almost invariably of the familial type. (2) "Familial retardates ... are almost invariably mildly retarded, usually with I.Q.'s above 50." And thus, physiologically defective retardates are almost invariably of the profound and severe type, with IQs below 50 (40?).

Among institutionalized retardates, in reference to Set 1 , our sample shows that retardates with IQs below 40 are primarily of the organic, or physiologically defective, type, but even a frequency as high as $75 \%$ of the profound retarded diagnosed organic cannot lead to the conclusion that profounds are "almost invariably" organic. The second half of Set 1 , which implies that retardates with above-40 IQs are almost invariably familial, is unsupported. Our data indicate a sizable percent of moderate $(12.59 \%)$ and mild $(5.82 \%)$ retardates are also diagnosed organic.

The second set of sentences also fails the criterion of "invariability." In the first instance, in fact, familial retardates primarily show IQs below 50, whereas over $18 \%$ of the physiologically defective type fall into the moderate and mild categories.

For institutionalized retardates, there is considerable variability in level of retardation among those classified cultural- familial. Until data on noninstitutionalized retardates with etiologies and measured intelligence allow comparison with our data, we can only speculate on the etiological make-up of the noninstitutionalized population. However, it seems reasonable to estimate a sizable percentage of noninstitutionalized retardates with IQs below 50 (a small minority, presumably, of noninstitutionalized retardates) would be of the culturalfamilial type, and considerable numbers of the noninstitutionalized retardates with IQs over 50 will be of the physiologically defective type.

What then of the "two-group approach in mental retardation"? Accepting the assumption under study, Zigler (1967) concluded that "this difference in the general intellectual level of the two groups of retardates is an important empirical phenomenon that supports the two-group approach to mental retardation" (p. 292).

We suggest that the empirical justification for the two-group approach is compelling and that the practical aspects of the approach remain even if the "below-above-50 IQ" rule of thumb is inapplicable. We suggest that "an important developmental component" (Zigler, 1969) allows the two-group approach to explain the difference between the two groups as well as the variability in IQ across etiologies.

An extension of Zigler's (1969) developmental model of cognitive growth (Figure 1) to the lowest end of the IQ scale, which our data justify for cultural-familial retardates as well as for organics, suggests that: (1) movement through or development through the cognitive levels or stages may be slow in the extreme (i.e., to Level 1 or 2 ) for some cultural-familial retarded, and (2) movement through or development through the cognitive levels or stages may occur at variable rates and to various levels (i.e., to Level $1,2,4$, or even 6 ) for the physiologically defective retarded.

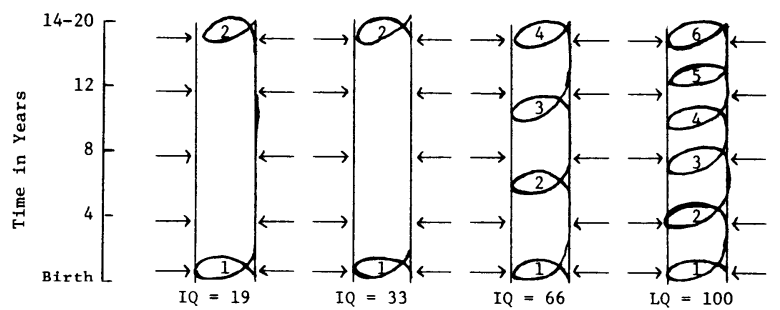

Figure 1. Extension of the developmental model of cognitive growth. "The single vertical arrow represents the passage of time. The horizontal arrows represent environmental events impinging on the individual who is represented as a pair of vertical lines. The individual's cognitive development appears as an internal ascending spiral, in which the numbered loops represent stages of cognitive growth" (Zigler, 1969, p. 538). 
These suggestions do not violate two-group theory. Rather, the heuristic value is increased, particularly as the above two suggestions may be understood as hypotheses. Moreover, these suggestions adhere to Zigler's (1969) call for workers in the field to utilize the two-group approach, to dichotomize the retarded on the basis of etiology, in order to enhance our understanding of the nature of cognitive development and functioning and correlates thereof. In this instance, our call is for acknowledgment of, and research on, the physiological and environmental correlates of the variable intellectural functioning of retardates such that large portions of the cultural-familial are below an IQ of 50 and portions of the physically defective are above an IQ of 50. Our data also show that the mild and moderate levels, those most subject to de-institutionalization efforts, still constitute a significant number of the institutional population.

\section{REFERENCE NOTE}

1. Penrose, L. S. A clinical and genetic study of 1,280 cases of mental defect (Special Report Series, No. 229). London: Medical Research Council, 1938.

\section{REFERENCES}

American Association on Mental Deficiency. Directory of residential facilities for the mentally retarded (prepared by
A.A.M.D. Division of Special Studies). Albany, N.Y: Author, 1968.

Cleland, C. C. Mental retardation: A developmental approach. Englewood Cliffs, N.J: Prentice-Hall, 1978.

Dingman, H. F., \& Eyman, R. K. Statistics in institutions for the mentally retarded. In A. Baumeister \& E. Butterfield (Eds.), Residential facilities for the mentally retarded. Chicago: Aldine, 1970.

Gladwin, T. Methodologies applicable to the study of learning deficits. American Journal of Mental Deficiency, 1959, 64, 311-315.

Heber, R. A manual on terminology and classification in mental retardation. American Journal of Mental Deficiency Monograph Supplement (rev. ed.). Washington, D.C: American Association on Mental Deficiency, 1961.

HutT, M., \& GiBBy, R. The mentally retarded child. Boston: Allyn \& Bacon, 1976.

Robinson, H. B., \& Robinson, N. M. The mentally retarded child. New York: McGraw-Hill, 1965.

SARASOn, S. Psychological problems in mental deficiency. New York: Harper \& Brothers, 1949.

ZIGLER, E. Familial mental retardation: A continuing dilemma. Science, 1967, 155, 292-298.

ZIGLER, E. Developmental versus difference theories of mental retardation and the problem of motivation. American Journal of Mental Deficiency, 1969, 73, 536-556.

(Received for publication April 23, 1980.) 